\title{
Analysis of the Initial Stage of Localized Corrosion on Zn and Zn Alloy Coated Steels by Photon Rupture Method
}

\author{
Masatoshi SAKAIRI, Kazuma ITABASHI ${ }^{11}$ and Hideaki TAKAHASHI \\ Graduate School of Engineering, Hokkaido University, Kita 13, Nishi 8, Kita-ku, Sapporo, 060-8628, Japan. \\ 1) NTT DoCoMo Hokkaido Inc., Kita 1, Nishi 14, Chuou-ku, Sapporo, 060-0001, Japan.
}

(Received on July 20, 2004; accepted in final form on September 20, 2004)

\begin{abstract}
A photon rupture method, film removal by a focused pulse of pulsed $\mathrm{Nd}$-YAG laser beam irradiation, has been developed as it enables oxide film stripping at extremely high rates without contamination from the film removal tools. In the present study, $\mathrm{Zn}$ and $\mathrm{Zn}-5 \mathrm{mass} \% \mathrm{Al}$ alloy coated steel specimens covered with protective nitrocellulose film were irradiated with a focused pulse of a pulsed Nd-YAG laser beam at a constant potential in $0.5 \mathrm{kmol} \mathrm{m}^{-3} \mathrm{H}_{3} \mathrm{BO}_{3}-0.05 \mathrm{kmol} \mathrm{m}^{-3} \mathrm{Na}_{2} \mathrm{~B}_{4} \mathrm{O}_{7}(\mathrm{pH}=7.4)$ with/without $0.05 \mathrm{kmol} \mathrm{m}^{-3}$ of chloride ions to investigate the initial stage of localized corrosion. At low potentials, both samples reformed oxide film after the nitrocellulose films were removed by this method. The oxide film formation kinetics of Zn-55mass\% Al follow an inverse logarithmic law, in agreement with Cabrera-Mott theory. However, at high potentials, localized corrosion producing corrosion products occured at the area where nitrocellulose film was removed. The dissolution current of the $\mathrm{Zn}$ coated steel samples is higher than that of $\mathrm{Zn}-5 \mathrm{mass} \% \mathrm{Al}$ coated samples at the same applied potential.
\end{abstract}

KEY WORDS: Zn-Al coated steel; localized corrosion; chloride ions; photon rupture method; current transient.

\section{Introduction}

Zinc and zinc alloys coated on steels give good corrosion-resistant properties and are widely used in numerous applications. The corrosion protection of the coated layers are ascribed to cathodic protection by galvanic reactions between coated layer and substrate, and the high corrosion resistance as due to the formation of compact corrosion products $^{1-3)}$. The composition of corrosion products formed on the steels caused by atmospheric corrosion has been investigated in various exposure conditions. ${ }^{4-7)}$ Oesch et al. ${ }^{8)}$ have reported the effect of air pollutants such as $\mathrm{SO}_{2}$ and $\mathrm{NO}_{2}$ on the corrosion of $\mathrm{Zn}$ and other light metals. The effect of corrosion products formed on electrodeposited zinc alloy coatings during atmospheric corrosion has also been reported. ${ }^{9)}$

When applying electrochemical methods such as voltammetry and electrochemical impedance spectroscopy (EIS) to the study of atmospheric corrosion there are some problems caused by the thin electrolyte layer. However, electrochemical techniques have recently been applied to measurements of atmospheric corrosion. ${ }^{10-17)}$ Nishikata et al. ${ }^{16)}$ have reported electrochemical corrosion monitoring of galvanized steel under cyclic wet-dry conditions. Peiez et al. ${ }^{18)}$ have also reported an EIS study of the corrosion process of coated galvanized steel in a salt spray condition.

Analysis of abruptly destroyed passive oxide films on metals and its repair is important to understand the localized corrosion of metals. An analysis of this behavior has been carried out by monitoring potential- or current- tran- sients after mechanically stripping the oxide films. Ford et $a l .{ }^{19)}$ and Burstein et $a l^{20-28)}$ have reported a re-passivation mechanism after removal of passive oxide film by the mechanically stripping technique. There are however problems with the mechanical film stripping techniques, such as low stripping rates, difficult to controling stripping area size of the oxide film and contamination from the stripping tools.

Recently, film stripping by high power laser beam irradiation, the photon rupture method, which resolves these problems, has been reported. This has been applied to iron electrodes by Oltra et al. $^{29,30)}$ and Itagaki et al., ${ }^{31)}$ and to aluminum electrodes by Sakairi et al. ${ }^{32)}$ and Takahahshi et $a l .{ }^{33)}$ Sakairi et $a l{ }^{34-40)}$ have also applied the photon rupture method to the initial stage of localized corrosion on coated steels in aqueous solutions with aggressive anions. They found that chloride ions enhance dissolution of the zinc and aluminum of the coated layers at the very initial period after laser irradiation.

In the present study, protective nitrocellulose film, which was formed on specimens, was removed by photon rupture at constant potentials in $0.5 \mathrm{kmol} \mathrm{m}^{-3} \mathrm{H}_{3} \mathrm{BO}_{3}-0.05 \mathrm{kmol}$ $\mathrm{m}^{-3} \mathrm{Na}_{2} \mathrm{~B}_{4} \mathrm{O}_{7}(\mathrm{pH}=7.4)$ with chloride ions to investigate the effect of potential and chloride ions at the initial stage of localized corrosion of $\mathrm{Zn}$ and $\mathrm{Zn}-5 \mathrm{mass} \% \mathrm{Al}$ coated layer.

\section{Experiments}

\subsection{Specimens}

Zinc and $\mathrm{Zn}-5 \mathrm{mass} \% \mathrm{Al}$ coated steel sheets (Nippon 
Steel Co.) were cut into $20 \times 20 \mathrm{~mm}$ coupons with handles. After cleaning ultra sonically, some samples were dipped in nitrocellulose/ethylacetate solution three times to form as about $30 \mu \mathrm{m}$ thickness protective nitrocellulose film on the samples

\subsection{Electrochemical Measurements}

After formation of the nitrocellulose film, the specimens were immersed in $0.5 \mathrm{kmol} \mathrm{m}^{-3} \mathrm{H}_{3} \mathrm{BO}_{3}-0.05 \mathrm{kmol} \mathrm{m}^{-3}$ $\mathrm{Na}_{2} \mathrm{~B}_{4} \mathrm{O}_{7}(\mathrm{pH}=7.4)$ with or without $0.05 \mathrm{kmol} \mathrm{m}^{-3} \mathrm{NaCl}$ solutions, and irradiated by a pulsed Nd-YAG laser (Sepctra Physics GCR-130) through a lens and quartz window at a constant potential, $E_{\mathrm{a}}$. The laser beam was the second harmonic wave, wave length $532 \mathrm{~nm}$, wave duration $8 \mathrm{~ns}$ and frequency $10 \mathrm{~s}^{-1}$, and the laser power was adjusted to $30 \mathrm{~mW}$ before the lens. The time of the irradiation was measured with a photo detector. The time for film removal in this study is the same as the time that the photo detector detected the laser beam.

The current transients of the nitrocellulose coated specimens after the laser irradiation were measured by a computer through an $\mathrm{A} / \mathrm{D}$ converter. The laser irradiation time was also detected by a photo-detector to investigate the irradiation time.

Polarization curves of the specimens were also measured by a potential scanning method, $0.3 \mathrm{mV} / \mathrm{s}$ in $0.5 \mathrm{kmol} \mathrm{m}^{-3}$ $\mathrm{H}_{3} \mathrm{BO}_{3}-0.05 \mathrm{kmol} \mathrm{m}^{-3} \mathrm{Na}_{2} \mathrm{~B}_{4} \mathrm{O}_{7}(\mathrm{pH}=7.4)$ with $0.05 \mathrm{kmol}$ $\mathrm{m}^{-3} \mathrm{NaCl}$ solutions.

A saturated $\mathrm{Ag} / \mathrm{AgCl}$ electrode was used as a reference electrode to measure the electrochemical data.

\subsection{Characterization}

After the electrochemical tests, specimen surfaces were examined by a confocal scanning laser microscope (CSLM).

\section{Results}

\subsection{Polarization Behavior}

Figure 1 shows the anodic polarization curves of $\mathrm{Zn}$ and $\mathrm{Zn}-5 \mathrm{mass} \% \mathrm{Al}$ coated steels in $0.5 \mathrm{kmol} \mathrm{m}^{-3} \mathrm{H}_{3} \mathrm{BO}_{3}-$ $0.05 \mathrm{kmol} \mathrm{m}^{-3} \mathrm{Na}_{2} \mathrm{~B}_{4} \mathrm{O}_{7} \quad(\mathrm{pH}=7.4) \quad$ solutions with 0.05 $\mathrm{kmol} / \mathrm{m}^{3} \mathrm{NaCl}$. The current increases with increasing potential after some incubation potential. The slope of the curve of the $\mathrm{Zn}-5 \mathrm{mass} \% \mathrm{Al}$ coated steel is steeper than that of the $\mathrm{Zn}$ coated steel. The rest-potentials of both samples are almost the same in this solution, however, the pitting potential of $\mathrm{Zn}$ coated steel is lower than that of $\mathrm{Zn}-5$ mass $\% \mathrm{Al}$ coated steel. The curve for the $\mathrm{Zn}$ coated steel is higher than that of $\mathrm{Zn}-5$ mass\%Alcoated steel.

Surface images a) $\mathrm{Zn}$ and b) $\mathrm{Zn}-5 \mathrm{mass} \% \mathrm{Al}$ coated steels after polarization tests are shown in Fig. 2. There is a lot of white colored corrosion product on both sample surfaces, caused by localized or pitting corrosion. These results suggest that the tip of such corroded areas do not reach the steel substrate.

\subsection{Film Removal at Rest Potential}

Figure 3 shows changes in the current, $I$, with time, $t$, obtained after laser irradiation in $0.5 \mathrm{kmol} \mathrm{m}^{-3} \mathrm{H}_{3} \mathrm{BO}_{3}-$ $0.05 \mathrm{kmol} \mathrm{m}^{-3} \mathrm{Na}_{2} \mathrm{~B}_{4} \mathrm{O}_{7}$ with $0.05 \mathrm{kmol} \mathrm{m}^{-3} \mathrm{NaCl}$ solutions

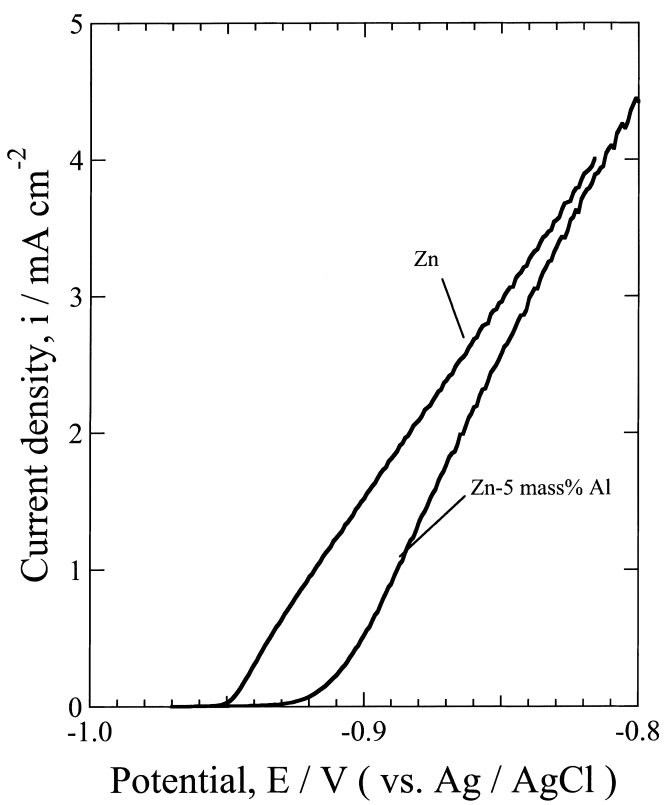

Fig. 1. Anodic polarization curves of $\mathrm{Zn}$ and $\mathrm{Zn}-5 \mathrm{mass} \% \mathrm{Al}$ coated steels in $0.5 \mathrm{kmol} \mathrm{m}^{-3} \mathrm{H}_{3} \mathrm{BO}_{3}-0.05 \mathrm{kmol} \mathrm{m}^{-3}$ $\mathrm{Na}_{2} \mathrm{~B}_{4} \mathrm{O}_{7}(\mathrm{pH}=7.4)$ solutions with $0.05 \mathrm{kmol} / \mathrm{m}^{3} \mathrm{NaCl}$.
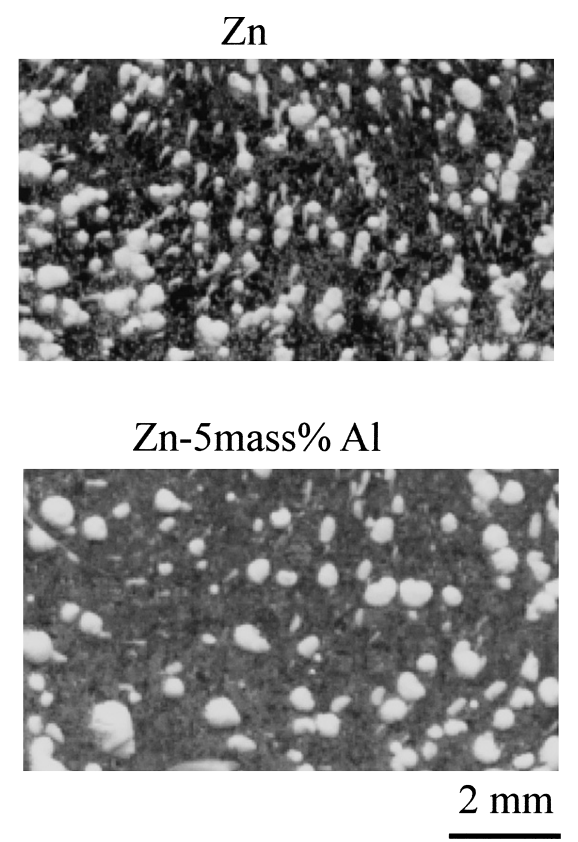

Fig. 2. Surface images of a) $\mathrm{Zn}$ and b) $\mathrm{Zn}-5 \mathrm{mass} \% \mathrm{Al}$ coated steels after polarization test.

at $-1000 \mathrm{mV} v s . \mathrm{Ag} / \mathrm{AgCl}$. The current of the $\mathrm{Zn}$ coated samples is smaller than that of the $\mathrm{Zn}-5$ mass $\% \mathrm{Al}$ coated sample. In both samples, the current transients show about $0.2 \mathrm{~ms}$ of induction before abrupt increases with current fluctuations and they show the maximum of current, $I_{\mathrm{p}}$, shortly after the increase and these is a decrease with time. The current fluctuations may be related to surface reconstruction, for example an electrical double layer formation and/or stabilization of the measurement system just after the nitrocellulose film was removed. In the case of the $\mathrm{Zn}-5 \mathrm{mass} \% \mathrm{Al}$ coated sample, current decreases follow a slope of -1 . This result means that the film formation kinetics follow an inverse logarithmic law, in agreement with 


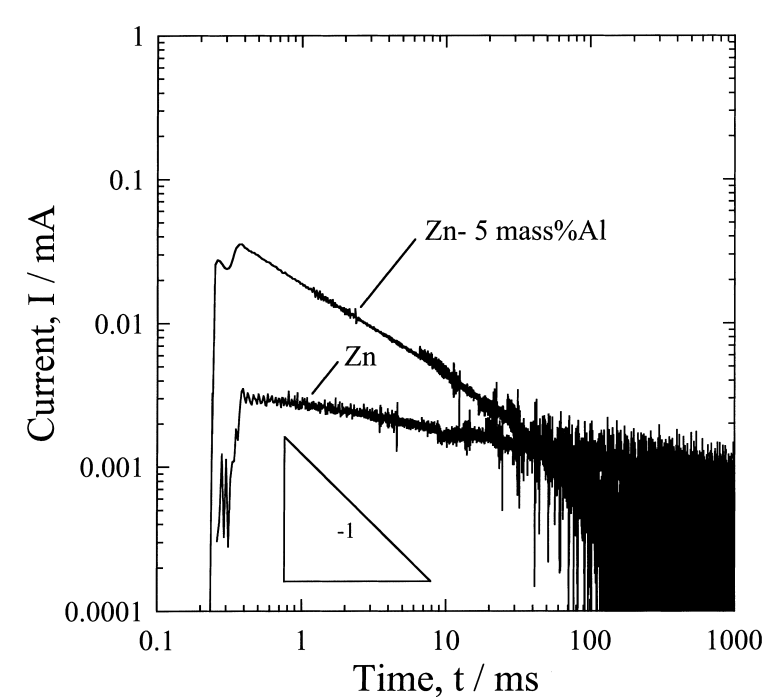

Fig. 3. Changes in current with time obtained after laser irradiation in $0.5 \mathrm{kmol} \mathrm{m}^{-3} \mathrm{H}_{3} \mathrm{BO}_{3}-0.05 \mathrm{kmol} \mathrm{m}^{-3} \mathrm{Na}_{2} \mathrm{~B}_{4} \mathrm{O}_{7}$ with $0.05 \mathrm{kmol} \mathrm{m}^{-3} \mathrm{NaCl}$ solutions at $-1000 \mathrm{mV}$ vs. $\mathrm{Ag} / \mathrm{AgCl}$.

Cabrera-Mott theory. However, the slope of the $\mathrm{Zn}$ coated sample is gentler than the slope of the $\mathrm{Zn}-5 \mathrm{mass} \% \mathrm{Al}$ coated sample.

The CSLM images of the sample surfaces after the experiment are shown in Fig. 4. The laser irradiated area is almost circular about $150 \mu \mathrm{m}$ in diameter, and it has a rough surface, and appears to have been quickly melted and solidified. The cross sectional observations show that the nitrocellulose films were completely removed by this technique. There are no corrosion products at the area where film was removed at the rest potential, which is in good agreement with current decreases follow a slope of -1 .

\subsection{Film Removal at Anodic Ppotentials}

Figure 5 shows changes in the current with time obtained after laser irradiation in $0.5 \mathrm{kmol} \mathrm{m}^{-3} \mathrm{H}_{3} \mathrm{BO}_{3}-$ $0.05 \mathrm{kmol} \mathrm{m}^{-3} \mathrm{Na}_{2} \mathrm{~B}_{4} \mathrm{O}_{7}$ with $0.05 \mathrm{kmol} \mathrm{m}^{-3} \mathrm{NaCl}$ solutions at $-800 \mathrm{mV}$. At this potential, the curves show a plateau at the initial stage between 0.2 and $1 \mathrm{~ms}$, then between 1 to $10 \mathrm{~ms}$ followed by a steady increase. The current of the $\mathrm{Zn}$ coated steel is smaller than that of $\mathrm{Zn}-5$ mass\% $\% \mathrm{Al}$ coated steel. This second increase in current, $t_{\mathrm{ri}}$, is a kind of incubation time for pitting or localized corrosion, which is usually determined in traditional corrosion tests, and this value becomes shorter at higher potentials. The slope of the current after $1 \mathrm{~ms}$ is gentler than that at $-1000 \mathrm{mV}$. This results suggests that metal dissolution also occurs after $1 \mathrm{~ms}$ at $-800 \mathrm{mV}$.

Figure 6 shows CSLM images of sample surfaces kept for $5 \mathrm{~s}$ at $-800 \mathrm{mV}$ after the nitrocellulose film was removed in $0.5 \mathrm{kmol} \mathrm{m}^{-3} \mathrm{H}_{3} \mathrm{BO}_{3}-0.05 \mathrm{kmol} \mathrm{m}^{-3} \mathrm{Na}_{2} \mathrm{~B}_{4} \mathrm{O}_{7}$ with $0.05 \mathrm{kmol} \mathrm{m}^{-3} \mathrm{NaCl}$. The shape and size of the area where nitrocellulose film was removed are very similar to those in Fig. 4. There are corrosion products, which are seen as black spots because of the lower reflectivity. The area of the corrosion products on the $\mathrm{Zn}-5$ mass $\% \mathrm{Al}$ coated steel is larger than that on $\mathrm{Zn}$ coated steel.

Figure 7 shows the relationship between the charges, $Q$ for $t=0$ to $1000 \mathrm{~ms}$ and the applied potentials. The $Q$ of the
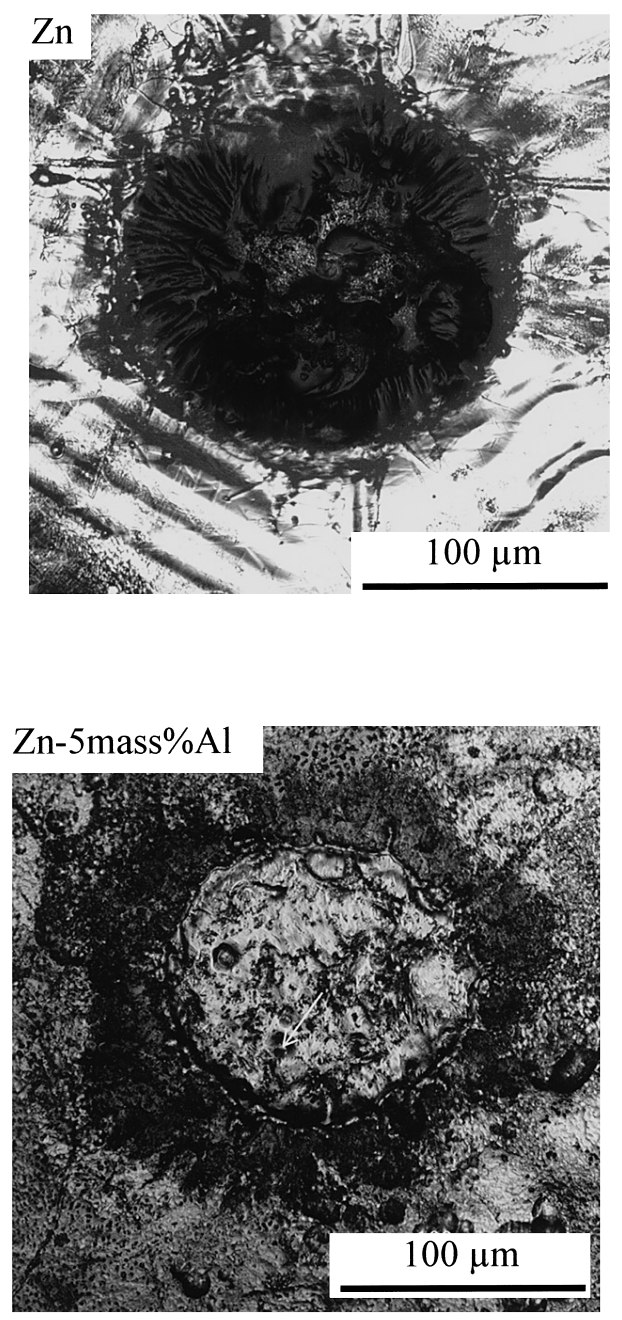

Fig. 4. CSLM images of sample surfaces maintained at $-1000 \mathrm{mV}$ for $5 \mathrm{~s}$ after nitrocellulose film removal in $0.5 \mathrm{kmol} \mathrm{m}^{-3} \mathrm{H}_{3} \mathrm{BO}_{3}-0.05 \mathrm{kmol} \mathrm{m}^{-3} \mathrm{Na}_{2} \mathrm{~B}_{4} \mathrm{O}_{7}$ with 0.05 kmol m ${ }^{-3} \mathrm{NaCl}$.

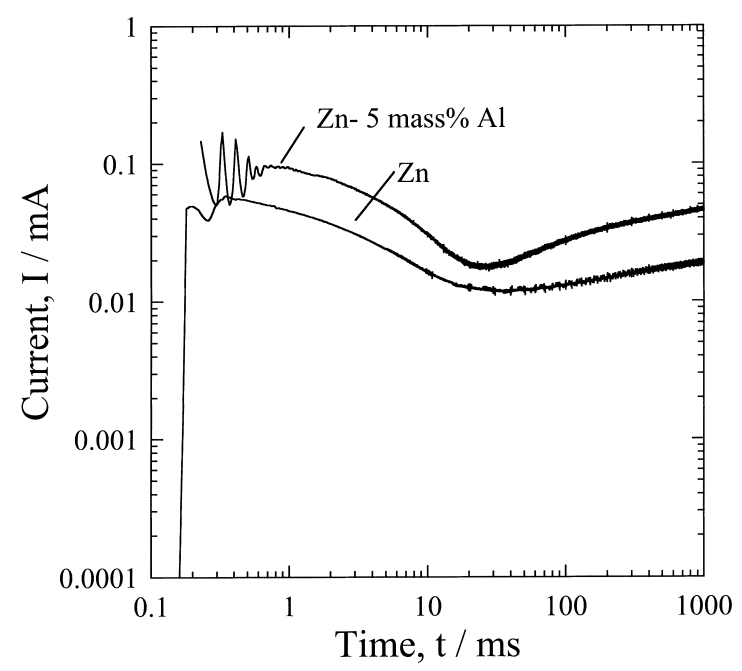

Fig. 5. Changes in current with time obtained after laser irradiation in $0.5 \mathrm{kmol} \mathrm{m}^{-3} \mathrm{H}_{3} \mathrm{BO}_{3}-0.05 \mathrm{kmol} \mathrm{m}^{-3} \mathrm{Na}_{2} \mathrm{~B}_{4} \mathrm{O}_{7}$ with $0.05 \mathrm{kmol} \mathrm{m}^{-3} \mathrm{NaCl}$ solutions at $-800 \mathrm{mV}$ vs. $\mathrm{Ag} / \mathrm{AgCl}$.

$\mathrm{Zn}$ coated samples are smaller than those of the $\mathrm{Zn}-5 \mathrm{mass} \% \mathrm{Al}$ at high potentials. At low potentials, the $Q$ does not show a clear dependence on the potential, however it increases with increasing potential at high potentials, re- 

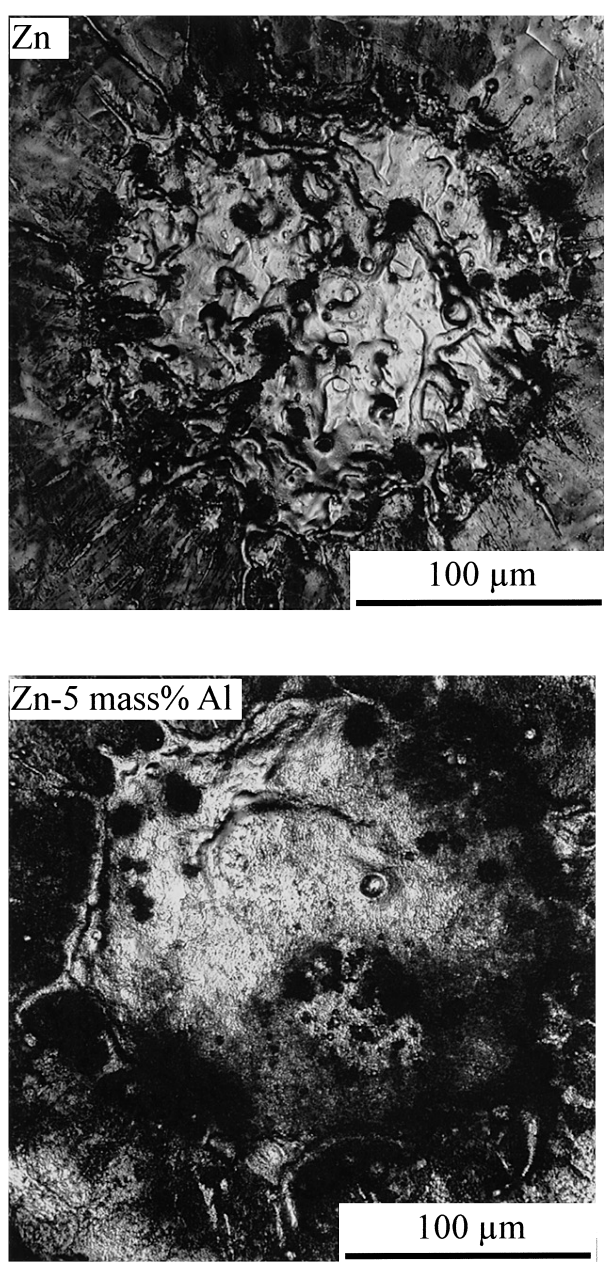

Fig. 6. CSLM images of sample surfaces maintained at $-800 \mathrm{mV}$ for $5 \mathrm{~s}$ after nitrocellulose film removal in $0.5 \mathrm{kmol} \mathrm{m}^{-3} \mathrm{H}_{3} \mathrm{BO}_{3}-0.05 \mathrm{kmol} \mathrm{m}^{-3} \mathrm{Na}_{2} \mathrm{~B}_{4} \mathrm{O}_{7}$ with 0.05 $\mathrm{kmol} \mathrm{m}^{-3} \mathrm{NaCl}$.

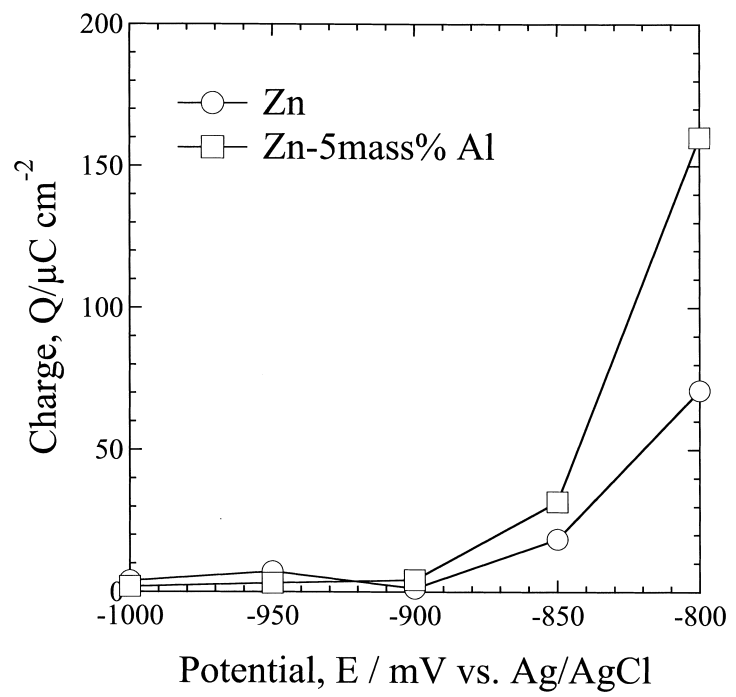

Fig. 7. Relationship between the charge, $Q$ for $t=0$ to $1000 \mathrm{~ms}$ in Figs. 3 and 4, and the potential.

lated to the current transients showing a second stage of increase after $10 \mathrm{~ms}$. These results are in good agreement with the current transients.

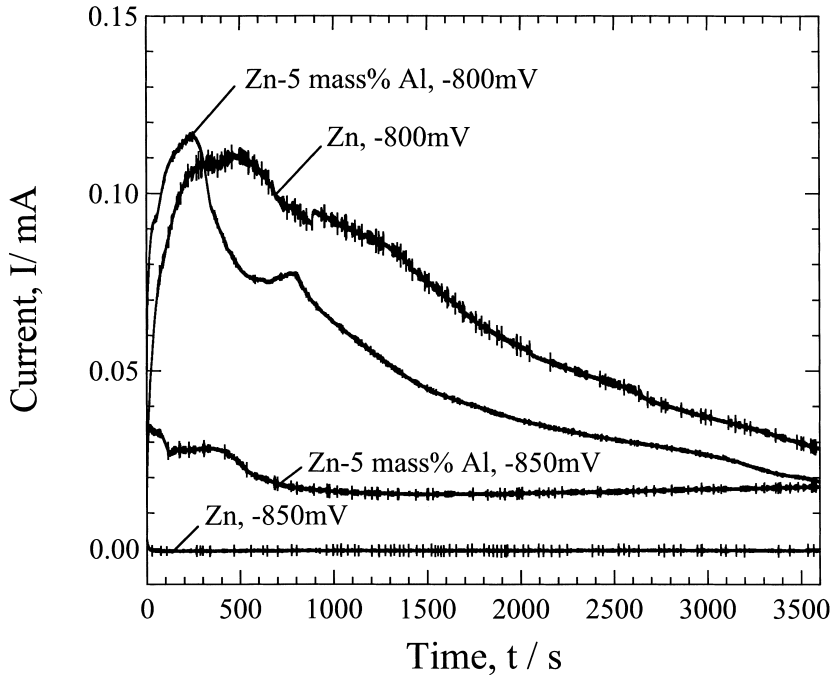

Fig. 8. Changes in current with time obtained after laser irradiation for long periods in $0.5 \mathrm{kmol} \mathrm{m}^{-3} \quad \mathrm{H}_{3} \mathrm{BO}_{3}-$ $0.05 \mathrm{kmol} \mathrm{m}^{-3} \mathrm{Na}_{2} \mathrm{~B}_{4} \mathrm{O}_{7}$ with $0.05 \mathrm{kmol} \mathrm{m}^{-3} \mathrm{NaCl}$ solutions at $-800 \mathrm{mV}$ and $-850 \mathrm{mV} v s$. $\mathrm{Ag} / \mathrm{AgCl}$.

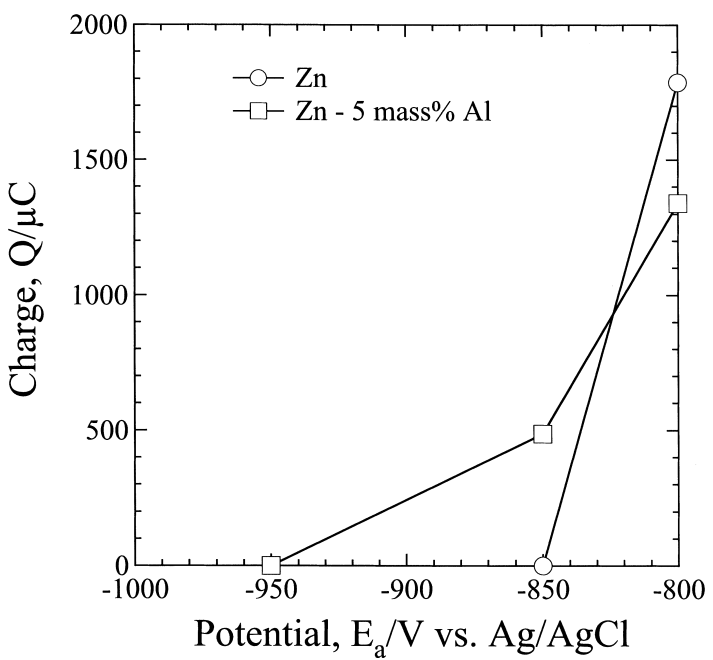

Fig. 9. Changes in the charge, $Q$ for $t=0$ to $3.6 \mathrm{ks}$ in Fig. $8 v \mathrm{~s}$. the applied potential.

\subsection{Long Time Polarization after Film Removal}

The effect of dipping time after nitrocellulose film removal at $-800 \mathrm{mV}$ and $-850 \mathrm{mV}$ vs. $\mathrm{Ag} / \mathrm{AgCl}$ were investigated. Figure 8 shows the changes in current with time obtained after laser irradiation for long periods. After the second stage of increase, the current shows a maximum and the decreases with time in both samples at $-800 \mathrm{mV} v s$. $\mathrm{Ag} / \mathrm{AgCl}$. The rate of current decrease with $\mathrm{Zn}$ coated steel is smaller than that of the $\mathrm{Zn}-5$ mass\%Al coated sample. The current change of $\mathrm{Zn}-5 \mathrm{mass} \% \mathrm{Al}$ coated steel at $-850 \mathrm{mV}$ is similar to those at $-800 \mathrm{mV}$, however the current of the $\mathrm{Zn}$ coated steel at $-850 \mathrm{mV}$ is very small.

Changes in the charge, $Q$ for $t=0$ to $3.6 \mathrm{ks}$ in Fig. 8, and the applied potential are shown in Fig. 9. The $Q$ of $\mathrm{Zn}-5 \mathrm{mass} \% \mathrm{Al}$ coated steel samples increase with increasing potential. The $Q$ of the $\mathrm{Zn}$ coated sample increases with increasing applied potential. Because, at applied potentials lower than $-850 \mathrm{mV}$, oxide film was formed just after laser irradiation. 

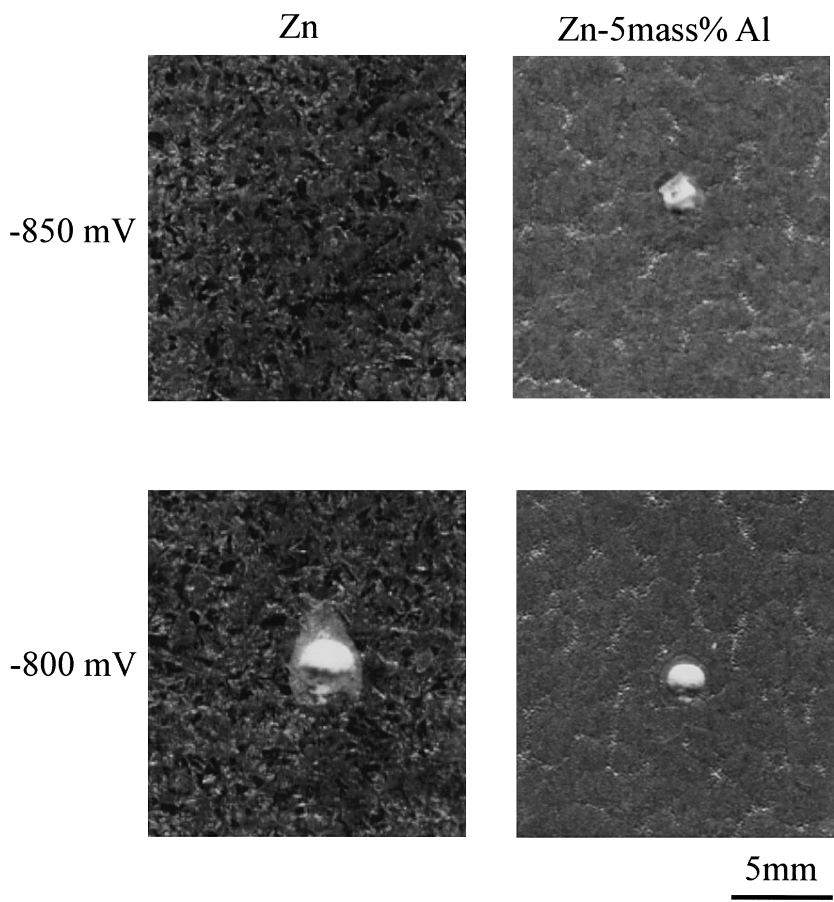

Fig. 10. Surface images of samples after polarization tests for $3.6 \mathrm{ks}$ after nitrocellulose film removal.

Figure 10 shows surface photographs after the long term immersion tests. White corrosion products can be seen on the $\mathrm{Zn}$ coated sample at $-800 \mathrm{mV}$ and on the $\mathrm{Zn}-5 \mathrm{mass} \% \mathrm{Al}$ coated samples. There is no corrosion products on the $\mathrm{Zn}$ coated sample at $-850 \mathrm{mV}$. The volume of corrosion products depend on the passed charge in Fig. 9.

\section{Discussion}

\subsection{Nitrocellulose Film Removal Mechanism}

Figure 11 is a schematic representation of the nitrocellulose film removal by laser irradiation. In the case of transparent films (zinc oxide and nitrocellulose films) on the coated layer, almost all of the irradiated laser beam reaches the metal-nitrocellulose film interface, and assuming that the reflectivity of zinc and aluminum are about $R=0.81$ at $532 \mathrm{~nm},{ }^{41)}$ the adsorbed power density, $E_{\text {ad }}$, is expressed by $E_{\mathrm{ad}}=4(1-R) P /\left[\pi \cdot D^{2} \cdot t_{\mathrm{p}}\right]$, where $P$ is irradiated laser power density, $D$ is diameter of irradiated area, $t_{\mathrm{p}}$ is the pulse duration. The $E_{\mathrm{ad}}$ in this experimental condition, $t_{\mathrm{p}}=8 \mathrm{~ns}$, $D=150 \mu \mathrm{m}$ and $P=3.0 \mathrm{~mJ} \quad(30 \mathrm{~mW} / 10 \mathrm{~Hz})$, becomes $4.1 \times 10^{12} \mathrm{~W} / \mathrm{m}^{2}$. According to Ready, ${ }^{42}$ the approximate expression for the minimum laser power density, $E_{\mathrm{av}}$, for ablation is expressed by $E_{\mathrm{av}}=2 \cdot L \cdot r \cdot k^{0.5} \cdot t_{\mathrm{p}}{ }^{-0.5}$, where $L$ the latent heat required to vaporize the solid metal, $k$ the thermal diffusibility, and $r$ the density of metal. In this case, $E_{\mathrm{av}}$ is calculated to be $0.65 \times 10^{12} \mathrm{~W} / \mathrm{m}^{2}$. The value of $E_{\text {ad }}$ in the present investigation appears to be much larger than that of $E_{\text {av }}$, and this strongly suggests that laser ablation will take place beneath the laser irradiated area just after irradiation. The ablation of metal produces pressure at the film/coated layer interface, and this pressure, $p$, can be calculated from $p=E_{\text {ad }} /\left\{r\left[L+C\left(T_{\mathrm{V}}-T_{0}\right)\right]^{2}\right\}^{43)}$, where $C, T_{0}$ and $T_{\mathrm{V}}$ are the specific thermal capacity of the metal, and the initial and vaporization temperatures of the metal leading to a calculated $p$ of about $10^{8} \mathrm{~Pa}$ for the coated layer. Simple calcula-

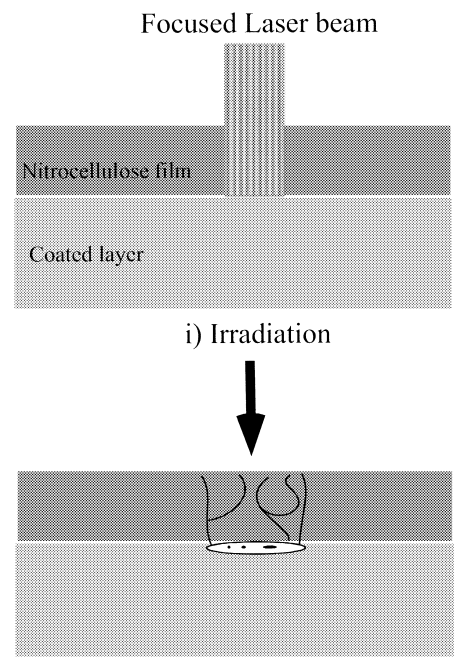

ii) Laser ablation at nitorocellulose film /coated layer interface

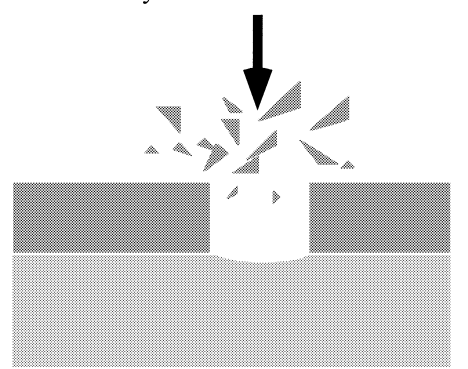

iii) Removal of nitrocellulose film

Fig. 11. Schematic drawing of the nitrocellulose film removal by laser irradiation.

tion of the volume change of solid to gas gives an estimated pressure of about $2 \times 10^{8} \mathrm{~Pa}$ at the laser irradiated area. It may then be considered that nitrocellulose and oxide films can be destroyed and removed by the high pressure at the oxide film/substrate interface produced by the laser ablation of metal.

\subsection{Localized Dissolution and Re-oxidation}

Figure 12 is a schematic model of the re-oxidation and localized dissolution after surface films were removed. The films were removed by laser irradiation and the coated metal exposed to the solution. The metals in the coating are oxidized electrochemically to $\mathrm{Zn}^{2+}$ and $\mathrm{Al}^{3+}$ ions, and these ions react with water to form oxide or hydroxide film on the exposed area. In the solution with chloride ions, oxide film is continuously reforming at low potentials. The current transients show a sudden increase, a maximum and a continuously decreases with a slope of about -1 in the chloride ion containing solutions. Here the aluminum dissolution forming aluminum-chloride complexes may compete with oxide film formation at high set potentials. The $\mathrm{Zn}$ also dissolves as zinc-aquo complexes, $\mathrm{Zn}^{2+}$ (aq), after the layer is exposed to the solution. Because of these reactions, the current did not decrease with time after the maximum and formed corrosion products at the area where film had been removd.

\section{Conclusions}

The present study investigated the effect of potential and 


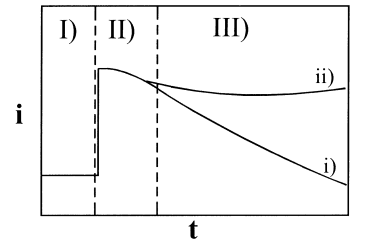

I) Film removal

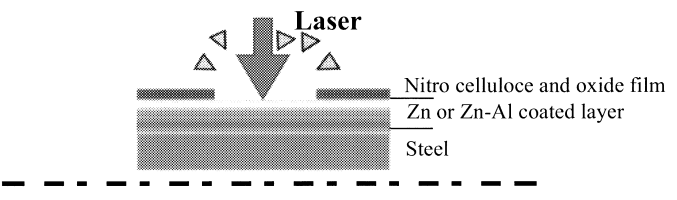

II) Dissolution + film repair

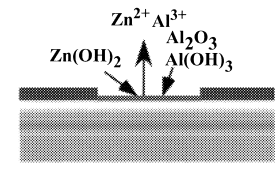

III)

i) Film repair

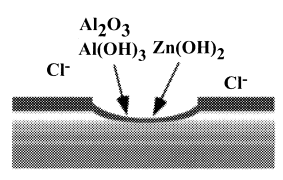

- at low potential ii) Localized corrosion Corrosion

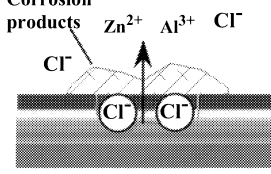

- at high potential
Fig. 12. Schematic model of film reformation and localized dissolution after film removal.

chloride ions at the initial stage of localized corrosion of a $\mathrm{Zn}$ and $\mathrm{Zn}-5 \mathrm{mass} \% \mathrm{Al}$ coated layer by photon rupture method and the following conclusions may be drawn.

(1) A nitrocellulose film, which was formed on the specimen by dipping can be removed locally by the photon rupture method. This nitrocellulose film showed good corrosion resistance during the experiments.

(2) Using nitrocellulose film as a protective film, the photon rupture method can be applied to localized corrosion study of $\mathrm{Zn}$ and $\mathrm{Zn}-5$ mass\% $\%$ Al coated steels, which do not form anodic oxide films, at different constant potentials in neutral solutions with $\mathrm{NaCl}$.

(3) In $0.5 \mathrm{kmol} \mathrm{m}^{-3} \mathrm{H}_{3} \mathrm{BO}_{3}-0.05 \mathrm{kmol} \mathrm{m}^{-3} \mathrm{Na}_{2} \mathrm{~B}_{4} \mathrm{O}_{7}$ solutions with chloride ions, oxide films are reformed at low potential after removal of the nitrocellulose film by the photon rupture method, however, localized corrosion occurs with formation of corrosion products in the chloride ion containing solutions at noble potentials where the nitrocellulose film was removed.

\section{Acknowledgement}

The authors wish to thank Nippon Steel Co. for providing the coated steel sheets. The authors are indebted for financial support from The Iron and Steel Institute of Japan and from the Japan Society for the Promotion of Science, a Grant-in-Aid for Encouragement of Young Scientists.

\section{REFERENCES}

1) G. X. Zhang: Corrosion and Electrochemistory of Zinc, Plenum Publication Co., New York, (1996).
2) Y. Hisamatsu: Bull. Jpn. Inst. Met., 20 (1981), 3.

3) Y. Miyoshi, J. Oka and S. Maeda: Trans Iron Steel Inst. Jpn., 23 (1983), 974.

4) T. E. Graedel: J. Electrochem. Soc., 136 (1989), 193C.

5) J. E. Svensson and L. G. Johansson: J. Electrochem. Soc., 143 (1996), 51.

6) J. E. Svensson and L. G. Johansson: Corros. Sci., 34 (1993), 721.

7) J. J. Frei: Corrosion, 42 (1986), 422.

8) S. Oesch and M. Faller: Corros. Sci., 39 (1997), 1505.

9) R. Ramanauskas, P. Quintana, P. Bartolo-Perez and L. Diaz-Ballote: Corrosion, 56 (2000), 588.

10) A. P. Yadav, A. Nishikata and T. Tsuru: Corros. Sci., 46 (2004), 361

11) A. P. Yadav, A. Nishikata and T. Tsuru: Corros. Sci., 46 (2004), 169.

12) G. A. El-Mahdy, A. Nishikata and T. Tsuru: Corros. Sci., 42 (2000), 1509.

13) R. P. Vera Cruz, A. Nishikata and T. Tsuru: Corros. Sci., 38 (1996), 1397.

14) A. Nishikata, Y. Yamashita, H. Katayama, T. Tsuru, A. Usami, K. Tanabe and H. Mabuchi: Corros. Sci., 37 (1995), 2069.

15) T. Tsuru, A. Nishikata and J. Wang: Mater. Sci. Eng. A, A19 (1995), No. 8,161 .

16) A. Nishikata, Y. Ichihara and T. Tsuru: Corros. Sci., 37 (1995), 897.

17) G. A. El-Mahdy, A. Nishikata and T. Tsuru: Corros. Sci., 42 (2000), 183.

18) C. Peiez, a. Collazo, M. Izquierdo, P. Merino and X. R. Novoa: Corrosion, 56 (2000), 1220.

19) F. P. Ford, G. T. Burstein and T. P. Hoar: J. Electrochem. Soc., 127 (1980), 1325.

20) G. T. Burstein and P. I. Marshall: Corros. Sci., 23 (1983), 125.

21) G. T. Burstein and R. C. Newman: Corros. Sci., 21 (1981), 119.

22) G. T. Burstein and R. C. Newman: Electrochim. Acta, 25 (1980), 1009.

23) G. T. Burstein and R. C. Newman: Electrochim. Acta, 26 (1981), 1143.

24) G.T. Burstein and R. C. Newman: J. Electroanal. Chem., 129 (1981), 343.

$25)$ G. T. Burstein and R. J. Cinderey: Corros. Sci., 32 (1991), 1195

26) R. J. Cindery and G. T. Burnstein: Corros. Sci., 33 (1992), 493.

27) G.T. Burstein and R. J. Cinderey: Corros. Sci., 33 (1992), 475.

28) R. J. Cinderey and G. T. Burstein: Corros. Sci., 33 (1992), 499.

29) R. Oltra, G. M. Indrianjafy and R. Roberge: J. Electrochem. Soc., 140 (1993), 343.

30) R. Oltra, G. M. Indrianjafy, M. Keddam and H. Takenouti: Corros. Sci., 35 (1993), 827.

31) M. Itagaki, R. Oltra, B. Vuillemin, M. Keddam and H. Takenouti: $J$. Electrochem. Soc., 144 (1997), 64.

32) M. Sakairi, Y. Ohira and H. Takahashi: Elctrochem. Soc. Proc., 97 (1997), No. 26, 643.

33) H. Takahahshi, M. Sakairi and Y. Ohira: Electrochem. Soc. Proc., 99 (1999), No. 27, 377.

34) M. Sakairi, K. Itabashi and H. Takahashi: Corros. Sci. Technol., 31 (2002), 426.

35) M. Sakairi, K. Itabashi and H. Takahashi: Proc. of Japan-China Joint Seminar on Marin Corrosion, Tokyo Inst. Tech., Tokyo, (2002), 58.

36) M. Sakairi, K. Itabashi and H. Takahashi: Electrochem. Soc. Proc., 2002 (2002), No. 24, 399.

37) M. Sakairi, K. Itabashi and H. Takahashi: Proc. of Int. Symp. Corro Sci. in the 21st Century, UMIST, Manchester, (2003), C093.

38) M. Sakairi, K. Itabashi and H. Takahashi: Zairyo-to-Kankyo, 52 (2003), 524.

39) M. Sakairi, K. Itabashi and H. Takahashi: Proc. of 13th APCCC, JSCE, Tokyo, (2003), 62.

40) M. Sakairi, K. Itabashi and H. Takahashi: Proc. of Galvatech'04, AIST, Warrendale, PA, (2004), 1035.

41) J. F. Ready: Industrial Application of Lasers, Academic Press, New York, (1978), 336.

42) J. F. Ready: Effect of High Power Laser Radiation, Academic Press, New York, (1971).

43) C. B. Scruby and L. El Drain: Laser Ultrasonics-Techniques and Applications-, Adam Hilger, New York, (1990), 232. 